\title{
Prediction of peak pressure from clinical and radiological measurements in patients with diabetes Nick A Guldemond ${ }^{* \dagger 1}$, Pieter Leffers ${ }^{\dagger 2}$, Geert HIM Walenkamp ${ }^{\dagger 1}$, Nicolaas C Schaper ${ }^{3}$, Antal P Sanders ${ }^{4}$, Fred HM Nieman ${ }^{5}$ and Lodewijk W van Rhijn ${ }^{1}$
}

Address: ${ }^{1}$ Department of Orthopaedic Surgery, University Hospital Maastricht, the Netherlands, ${ }^{2}$ Department of Epidemiology, University Maastricht, the Netherlands, ${ }^{3}$ Department of Rehabilitation Medicine, University Hospital Maastricht, the Netherlands, ${ }^{4}$ Department of Internal Medicine, University Hospital Maastricht, the Netherlands and ${ }^{5}$ Department of Clinical Epidemiology and Medical Technology Assessment, University Hospital Maastricht, the Netherlands

Email: Nick A Guldemond* - ngu@orthop.unimaas.nl; Pieter Leffers - p.leffers@epid.unimaas.nl; Geert HIM Walenkamp - gwa@sort.azm.nl; Nicolaas C Schaper - nsc@sint.azm.nl; Antal P Sanders - asan@rev.azm.nl; Fred HM Nieman - fni@oazg.azm.nl; Lodewijk W van Rhijn - lvr@sort.azm.nl

* Corresponding author †Equal contributors

Published: 2 December 2008

BMC Endocrine Disorders 2008, 8:16 doi:10.1186/1472-6823-8-16
Received: 23 January 2008

Accepted: 2 December 2008

This article is available from: http://www.biomedcentral.com/I472-6823/8//6

(C) 2008 Guldemond et al; licensee BioMed Central Ltd.

This is an Open Access article distributed under the terms of the Creative Commons Attribution License (http://creativecommons.org/licenses/by/2.0), which permits unrestricted use, distribution, and reproduction in any medium, provided the original work is properly cited.

\section{Abstract}

Background: Various structural and functional factors of foot function have been associated with high local plantar pressures. The therapist focuses on these features which are thought to be responsible for plantar ulceration in patients with diabetes. Risk assessment of the diabetic foot would be made easier if locally elevated plantar pressure could be indicated with a minimum set of clinical measures.

Methods: Ninety three patients were evaluated through vascular, orthopaedic, neurological and radiological assessment. $A$ pressure platform was used to quantify the barefoot peak pressure for six forefoot regions: big toe (BT) and metatarsals one $(M T-I)$ to five (MT-5). Stepwise regression modelling was performed to determine which set of the clinical and radiological measures explained most variability in local barefoot plantar peak pressure in each of the six forefoot regions. Comprehensive models were computed with independent variables from the clinical and radiological measurements. The difference between the actual plantar pressure and the predicted value was examined through Bland-Altman analysis.

Results: Forefoot pressures were significant higher in patients with neuropathy, compared to patients without neuropathy for the whole forefoot, the MT-I region and the MT-5 region (respectively $138 \mathrm{kPa}, 173 \mathrm{kPa}$ and $88 \mathrm{kPa}$ higher: mean difference). The clinical models explained up to 39 percent of the variance in local peak pressures. Callus formation and toe deformity were identified as relevant clinical predictors for all forefoot regions. Regression models with radiological variables explained about 26 percent of the variance in local peak pressures. For most regions the combination of clinical and radiological variables resulted in a higher explained variance. The Bland and Altman analysis showed a major discrepancy between the predicted and the actual peak pressure values.

Conclusion: At best, clinical and radiological measurements could only explain about 34 percent of the variance in local barefoot peak pressure in this population of diabetic patients. The prediction models constructed with linear regression are not useful in clinical practice because of considerable underestimation of high plantar pressure values. Identification of elevated plantar pressure without equipment for quantification of plantar pressure is inadequate. The use of quantitative plantar pressure measurement for diabetic foot screening is therefore advocated. 


\section{Introduction}

Clinical examination is considered important in the evaluation of the diabetic foot. Physicians and foot care specialists should be able to identify patients at risk of adverse outcomes such as ulceration. A structured clinical assessment that incorporates diagnostic tests alongside a thorough history and examination is thought to be essential for preventive strategies[1]. High plantar pressures have been shown to be related to development of foot ulcers in people with diabetes. However, no study has assessed the relative importance of clinical examination in relation to the prediction of peak pressure.

Various structural and functional factors of foot function have been associated with high local plantar pressures such as limited joint mobility [2-4], plantar soft tissue thickness, stiffness and callosities [5-17], metatarsal length [18-20], the configuration of the medial longitudinal arch [21-24], the presence of metatarsal deformities[25,26] and toe deformities[27,28]. These features are associated with locally elevated plantar pressure which could cause plantar ulceration in patients with diabetes. To decide whether a diabetic foot is at risk, foot care specialists make an inventory of these features through observation, physical examination and radiographic evaluation. Risk assessment of the diabetic foot would be made easier if locally elevated peak pressure could be indicated with a minimum set of commonly used clinical measures.

An alternative diagnostic screening method for abnormal physical stress on the foot sole is direct quantitative measurement of plantar pressure. In the last few decades electronic devices such as pressure sensitive platforms have become commercially available for this purpose. This equipment is relatively expensive and there is no reimbursement by health insurers of the costs for the provision of this screening procedure. Consequently, this diagnostic facility is seldom provided as standard care in clinical settings.

The primary objective of this study was to assess the relationship between clinical measurements, radiological data and barefoot plantar pressure in order to find clinical measures that predict local peak pressure in patients with diabetes. In addition, we also evaluated previously proposed regression models by various authors with the same and/or similar variables as those obtained in our current study. To evaluate the effect of peripheral neuropathy as a predictor in this study, we included both patients with and without peripheral neuropathy. The secondary objective of this study was to assess the differences in clinical measurements, radiological data and barefoot peak pressure between patients with - and without peripheral neuropathy.

\section{Methods \\ Patients}

Diabetic patients were selected from the outpatient clinic of the University Hospital Maastricht. Inclusion criteria were diabetes mellitus type 1 (longer than 10 years after date of diagnosis) or type 2 (at least one year after date of diagnosis); age between 30 and 75 years and able to perform daily-life activities without supporting devices. Exclusion criteria were a history of rheumatoid arthritis, severe foot trauma, severe deformity i.e. which require orthopaedic shoes and/or surgery of the foot.

Before the start of the study, patients were informed about all study procedures and their possible risks. The Research Ethical Committee of the University Hospital Maastricht approved the study. One hundred and twenty five eligible patients were screened for peripheral neuropathy through determination of the vibration perception threshold (VPT) at the apex of the hallux with a biothesiometer (Biomedical, Newbury OH)[29,30]. A VPT higher than 25 Volts was used as the diagnostic criterion for peripheral

Table I: Patient characteristics

\begin{tabular}{|c|c|c|c|c|c|c|c|c|c|c|c|c|}
\hline & \multicolumn{6}{|c|}{ PNP- } & \multicolumn{6}{|c|}{ PNP+ } \\
\hline$n$ & \multicolumn{6}{|c|}{49} & \multicolumn{6}{|c|}{44} \\
\hline Gender (female/male) & \multicolumn{6}{|c|}{$30 / 19$} & \multicolumn{6}{|c|}{$29 / 15$} \\
\hline \multirow[t]{3}{*}{ Type of DM (I/2) } & \multicolumn{6}{|c|}{$|8 / 3|$} & \multicolumn{6}{|c|}{$9 / 35$} \\
\hline & \multicolumn{3}{|c|}{ female } & \multicolumn{3}{|c|}{ male } & \multicolumn{3}{|c|}{ female } & \multicolumn{3}{|c|}{ male } \\
\hline & Mean & SD & Range & Mean & SD & Range & Mean & SD & Range & Mean & SD & Range \\
\hline Age $(y r)$ & 56.3 & 9.1 & 35 & 50.9 & 9.5 & 38 & 64.9 & 8.8 & 26 & 58.8 & 10.4 & 44 \\
\hline Duration diabetes (yr) & 13.8 & 10.2 & 36 & 11.6 & 7.7 & 31 & 18.1 & II.4 & 38 & 16.3 & II.4 & 42 \\
\hline $\mathrm{HBalc}$ (percent) & 8.31 & 1.5 & 4.8 & 8.15 & I.I & 46 & 8.25 & 1.3 & 5.5 & 8.16 & 1.3 & 6.3 \\
\hline $\mathrm{BMI}\left(\mathrm{kg} / \mathrm{m}^{2}\right)$ & 28.9 & 5.2 & 19.8 & 28.2 & 4.8 & 17.9 & 31.2 & 7.4 & 25.7 & 29.6 & 6.5 & 27.3 \\
\hline
\end{tabular}

VPT = vibration perception threshold, PNP+ = peripheral polyneuropathy (VTP $>25$ Volts), PNP- = no peripheral polyneuropathy (VPT $\leq 25$ Volts), $\mathrm{DM}=$ diabetes mellitus, $\mathrm{HbAlc}=$ hemoglobin $\mathrm{Alc}, \mathrm{yr}=$ year, $\mathrm{BMI}=$ Body Mass Index 
neuropathy. Table 1 contains descriptive data with respect to gender, age, body mass index (BMI), duration of diabetes and glycosylated haemoglobin (HBa1c). Thirty two patients were excluded because of corrupted plantar pressure data due to technical failure. Finally, data of 93 patients were used for analysis. None of the subjects had a history of foot ulceration.

\section{Barefoot plantar pressure measurement}

An EMED SF-4 ${ }^{\circledast}$ pressure sensitive platform (Novel, Munich) was used to quantify the barefoot plantar pressures of the patients' feet and was performed according to a one-step protocol[31,32]. Barefoot peak pressure was estimated per foot by calculating the mean over the readings of 5 steps. This was done for the whole forefoot and six separate forefoot regions: big toe and metatarsals one (MT-1) to five (MT-5) through weight-bearing anteriorposterior radiographs and Novel 'clinics ${ }^{\circledR 1}$ software[33].

Prior to data collection the grade of callus formation under the plantar aspect of the hallux and the metatarsals' heads was scored according to the method described by Colagiuri et al[17] (1995). The definitions of scores were: grade 1) Distinct area with minimal thickening of keratin layer, grade 2) moderate thickening of keratin layer, grade 3) marked thickening of keratin layer. The callus formation was not removed prior to the data collection, because this was a factor of interest in the prediction of peak pressure.

\section{Peripheral neurological assessment}

The 'Valk' scoring system[34] for clinical neurological examination was performed to assess the grade of polyneuropathy. Pinprick sense and light touch sense (cotton wool) of the dorsum of the foot was tested on the mid-foot and compared to the proximal quality of sensation of the ankle. The quality of the vibration sense was tested with a $128 \mathrm{~Hz}$ tuning fork. The vibration sense of the big toe was compared to the vibration sense of the ankle, and the vibration sense of the ankle was compared to the patella. The ankle reflex action was compared to the knee reflex action. Pinprick sense, light touch sense, vibration sense of toes and ankles, and ankle reflexes were separately scored for both feet. Criteria for scoring for: normal (0), impaired in comparison with proximal (1) and absent (2), summing up to a maximum score of 20 points. Additionally, light touch sense was related to the anatomical level below which it was impaired: no abnormalities (0), toe (1), mid-foot (2), ankle (3), mid-calf (4) and knee (5). The outcome of the total score could vary between 0 and 25. According to Valk et al (1997) a score higher than 4 was graded as peripheral polyneuropathy[35].

\section{Orthopaedic assessment}

The passive ankle joint dorsal flexion range of motion was measured through use of a plastic goniometer with the patient in prone position and the knee flexed[36]. The range of dorsiflexion of the first metatarsophalangeal joint relative to the first metatarsal shaft was measured in a non-weight bearing position. The bisection lines of the goniometer were placed along the medial shaft of the first metatarsal and the proximal phalanx of the hallux. The degree of hallux valgus was measured in accordance with the guidelines of the American Academy of Orthopaedic Surgeons[37].

The presence of claw toe, mallet toe, curly toe or hammer toe deformity was scored according to the definitions described by Myerson and Shereff[27]. These definitions were used as references for classification of the degree of toe deformity. Accordingly, toe alignment could be normal or deformed as defined by Myerson and Shereff: i.e. 'normal toe' was recorded if there was no deformity present. In addition, less and more malalignment than the definitions described by Myerson and Shereff was arbitrarily classified as minor and severe.

From a dorsal view, a crude judgement of the resting calcaneal stance position was made through visual inspection while the patient was in standing at rest position. The resting calcaneal stance position was recorded as neutral, varus or valgus alignment. In addition, the medial arch height was subjectively classified into: no arch (pes planus); lowered arch; normal arch; elevated arch and excessively elevated arch.

\section{Vascular assessment}

For vascular tests, the patient lay supine and rested for at least 15 minutes prior to testing. A standard examination protocol for each lower extremity was performed. Resting ankle-brachial index (ABI) was obtained through continuous wave Doppler technique and performed at a 45 degree angle to the skin. Ankle-brachial index was calculated with the highest Doppler derived systolic pressure at the ankle (dorsalis pedis or posterior tibialis artery), indexed to the highest Doppler derived brachial artery pressure.

A Hokanson CE-4 strain gauge and photoplethysmograph was used to obtain toe pressure. A suitably sized cuff was wrapped around the proximal phalanx of the hallux. Once the best signal was acquired, the cuff was inflated until the signal disappeared, after which the cuff was slowly deflated until the signal reappeared (Application note: 85315, Hokanson D. E., Inc. Bellevue; WA, USA.). This was taken as the toe systolic pressure. Settings of equipment for all vascular assessment procedures were 
standardized. All measurements were carried out by the same experimenter. Each measurement was done three times, with the mean used for analysis.

\section{Radiographic evaluation}

Measurements from standardized static weight-bearing foot radiographs have been shown to be an objective and reliable way of assessing both bony structure and soft tissue dimensions [38-42]. Weight-bearing anterior-posterior and lateral radiographs were taken with the subject standing on a platform with the central beam for the lateral view (55 kV, $8 \mathrm{mAs}$ ) directed horizontally at the plantar aspect of the base of the first metatarsal and the first cuneiform from a distance of $100 \mathrm{~cm}$. For the anterior-posterior view (55 kV, $12 \mathrm{mAs}$ ), the beam was directed at the navicular from a distance of $150 \mathrm{~cm}$. This radiographic protocol was previously described by Cavanagh et al[43]. A radio-opaque marker was placed on the radiographic plate in order to judge afterwards whether scale correction was necessary.

All radiographs were taken by the same radiographer, using the same equipment and settings. Measurements were taken through line drawing and a protractor was used to measure the angles. Nine angular and six linear measurements were determined from the lateral radiographs. Five angular and thirteen linear measurements were determined from the anterior-posterior radiographs. All measurements were taken by the same experimenter.

\section{Statistical analysis}

To meet assumptions of normality of statistical distributions peak plantar pressure scores were natural log transformed. At first, data from 186 feet were used for analysis. Repeated measures ANOVA showed no statistical significant differences between left and right feet as a general effect in the repeated measures model, nor specified for the peak pressures scores (i.e. the interactions of peak pressure with left or right side), nor specified for regional peak pressure (i.e. the interactions of regional peak pressure with left or right side). Therefore it was legitimate in the eventual data analysis to average scores over left and right sides.

Next, stepwise regression analysis modelling was performed to determine which of the clinical or radiological measures will explain how much of the variance in averaged local barefoot plantar peak pressure, in each of the six forefoot regions and the whole forefoot separately. At first, all potential predictors of each subsets (clinical or radiological) were entered into the regression model through 'forward selection' and the resulting model with predictors having only statistical significant effects were noted. In the second step, all potential predictors are entered simultaneously and 'backward elimination' was applied until a model was found with predictors having statistical significant effects only. Finally, a cross-section of both resulting models was made using predictors having statistically significant effects in both models and this cross-section of predictors is 'force-entered' into the final regression model[44,45]. Comprehensive models are assembled from the significant effects of both clinical or radiological predictors following the same three-step procedure. Previously found results from literature were compared with results from our procedure. All regression analysis models were performed using list wise deletion of missing cases. To prevent type I error as much as possible in the multiple use of regression analysis, a Bonferroni correction was applied through the division by the number of plantar regions. Therefore, an alpha level of 0.01 was chosen to judge statistical significance.

To evaluate the prediction models for each individual patient the difference between the predicted value and the actual value was plotted against their mean. This method is also known as residual analysis. In the clinical literature this method is recognized as Bland-Altman analysis, which allows one to judge the agreement between two different measurement techniques[46]. Categorical data were analysed with Chi-square statistics. All data were analysed with SPSS $13.0^{\circledR}$ (SPSS Inc., Chicago, USA).

\section{Results \\ Differences between feet with and without neuropathy Plantar pressure}

Forefoot pressures were significant higher in patients with neuropathy, compared to patients without neuropathy for the whole forefoot, the MT- 1 region and the MT-5 region (respectively $138 \mathrm{kPa}, 173 \mathrm{kPa}$ and $88 \mathrm{kPa}$ higher: mean difference), table 2.

\section{Clinical measurements}

There were no were statistically significant differences between extremities with and without neuropathy with respect to the ankle-brachial index, toe pressure and passive dorsal flexion range of the ankle joint ( $\mathrm{p}$-values $\geq$ $.126)$.

The range of dorsal flexion motion of the MT- 1 joint was statistically significantly greater in feet without neuropathy compared to neuropathic feet: 15 degrees. The hallux valgus angle measured with a goniometer was statistically significantly greater in diabetic feet: 5.3 degrees (table 3 ).

\section{Callus formation and toe deformity}

The distributions of callus formation and toe deformity grades were similar for both feet with and without neuropathy (figures 1 and 2). Most important callus formation was found under the hallux and the head of MT-1, 
Table 2: Barefoot plantar peak pressure (kPa)

\begin{tabular}{|c|c|c|c|c|c|c|}
\hline & \multicolumn{3}{|c|}{ PNP- (106 feet) } & \multicolumn{3}{|c|}{ PNP+ (80 feet) } \\
\hline & Mean & SD & Min- Max & Mean & SD & Min- Max \\
\hline **Whole forefoot & 551 & 226 & $234-1218$ & 689 & 279 & $288-1262$ \\
\hline Big toe & 455 & 264 & $81-1180$ & 405 & 257 & $24-1070$ \\
\hline$* * M T-I$ & 308 & 138 & $90-801$ & 481 & 313 & $132-1260$ \\
\hline MT-2 & 475 & 226 & $160-1210$ & 551 & 271 & $199-1220$ \\
\hline MT-3 & 429 & 168 & $187-1120$ & 462 & 202 & $152-1000$ \\
\hline MT-4 & 288 & 102 & $140-660$ & 311 & 149 & $125-1020$ \\
\hline$*$ MT-5 & 224 & 147 & $70-782$ & 312 & 238 & $66-1060$ \\
\hline
\end{tabular}

PNP versus $\mathrm{PNP}+*_{\mathrm{p}}<0.05$ \& **p $<0.005$

while the least callus formation was found under the lateral side of the forefoot: MT-3 to MT-5.

For both groups the grade of toe deformity increased from the first to the fifth toe. No statistically significant differences for callus formation and toe deformity were found (p-values > .056), except that neuropathic feet had a slightly higher grade of deformity of the $4^{\text {th }}$ and $5^{\text {th }}$ toe (pvalues <.042).

\section{Calcaneal alignment}

The proportions for classification of the calcaneal resting position for feet with and without neuropathy was: 'neutral' 47.2 percent versus 51.2 percent; 'valgus' 46.2 percent versus 47.5 percent and 'varus' 6.6 percent versus 1.3 percent, respectively.

\section{Arch height}

The proportions of arch height classification for patients with and without neuropathy were: 'no arch' 6.6 percent versus 13.8 percent; 'lowered arch' 42.5 percent versus 31.3 percent; 'normal arch' 17.9 percent versus 21.1 percent; 'elevated arch' 26.4 percent versus 32.5 percent and 'excessively elevated arch' 6.6 percent versus 1.3 percent.

No statistically significant differences between neuropathic feet and feet without neuropathy for both calcaneal resting position and arch height were found ( $\mathrm{p}>.062)$.

\section{Radiographic evaluation}

The statistically significant differences for patients with neuropathy compared to patients without neuropathy listed as radiographic measures in millimetres $(\mathrm{mm})$ and degrees (deg) were: MT-5 base height $-0.6 \mathrm{~mm}$, navicular height $-3.7 \mathrm{~mm}$, inferior calcaneal inclination -2.9 deg, Chopart's joint angle $-1.4 \mathrm{deg}$, Lisfranc's joint angle +2.0 $\mathrm{deg}$, MT-5 inclination $-1.5 \mathrm{deg}$, MT-1 inclination $-1.6 \mathrm{deg}$, Talar inclination $+3.0 \mathrm{deg}$, 1 st PIP joint inclination -2.1 $\mathrm{deg}$, hallux valgus $+2.4 \mathrm{deg}$, MT-2 thickness $+0.4 \mathrm{~mm}$ and MT-3 thickness $+0.4 \mathrm{~mm}$ (table 4 ).

\section{Prediction of barefoot plantar peak pressure Regression models}

With a maximum of 5 predictors, the regression models with clinically independent variables explained up to 34 percent of variance of local peak pressures (table 5). The regression models with clinical variables explained more variance for the medial forefoot and the hallux than for the lateral forefoot. Callus formation was a relevant clinical predictor for all regions and the 'Valk score' for two regions and the whole forefoot. For the hallux region, the best model with 24 percent of explained variance of peak pressure was also achieved with clinical variables.

The regression model with radiological variables for the forefoot peak pressure with 4 predictors explained 18 percent of the variance of plantar pressure. The model for the

Table 3: Clinical measurements

\begin{tabular}{|c|c|c|c|c|c|c|}
\hline & \multicolumn{3}{|c|}{ PNP- } & \multicolumn{3}{|c|}{ PNP+ } \\
\hline & Mean & SD & Min-Max & Mean & SD & Min-Max \\
\hline **Vibration Perception Threshold & 13,78 & 5,05 & $4,8-25$ & 43,55 & 8,82 & $25,2-50$ \\
\hline$* *$ Valk score & 2,1 & 3,1 & $0-15$ & 12,9 & 7,3 & $0-24$ \\
\hline Ankle-Arm index & 1,06 & 0,19 & $0,52-1,83$ & 1,08 & 0,28 & $0,63-2,3$ \\
\hline Toe pressure & 109,5 & 29,8 & $47,5-200$ & 113,8 & 36,9 & $44-255$ \\
\hline Dorsal flexion ankle joint & 10 & 6,4 & $-5-25$ & 9 & 6,9 & $-5-25$ \\
\hline **Dorsal flexion motion MT-I joint & 93 & 16,8 & $45-150$ & 78 & 16,0 & $40-110$ \\
\hline$* *$ Hallux valgus angle & I I, I & 5,6 & $0-25$ & 16,4 & $\mathrm{I} \mid, 4$ & $0-50$ \\
\hline
\end{tabular}

**PNP- versus PNP+ $\mathrm{p}<0.005$ 


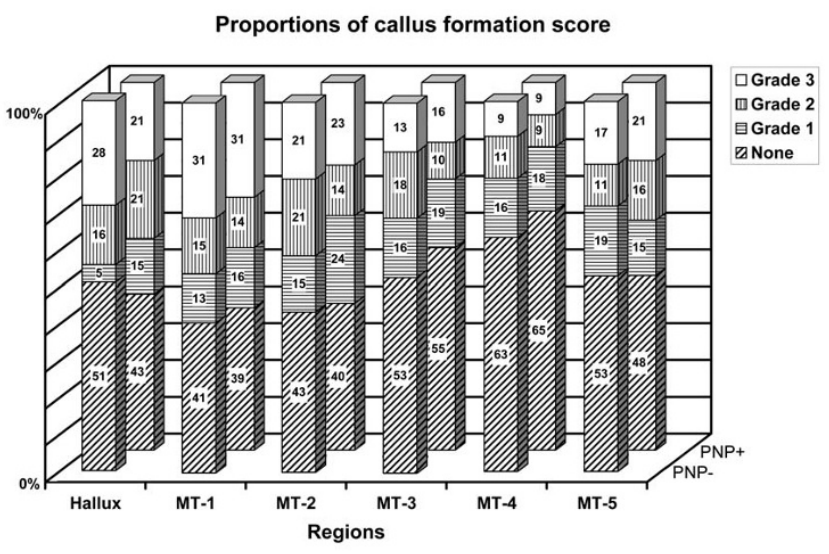

Figure I

Proportions of callus formation score, as a percentage, for patients with and without neuropathy. None $=$ no thickening of keratin layer, Grade I = Distinct area with minimal thickening of keratin layer, Grade 2 = moderate thickening of keratin layer, Grade $3=$ marked thickening of keratin layer. $M T=$ metatarsal, PNP - = without neuropathy, $\mathrm{PNP}+=$ with neuropathy.

MT-5 region explained no more than 22 percent of the variance, which was the best result with radiological variables compared to the models for the other regions.

For most regions, the comprehensive model i.e. the combination of clinical and radiological predictors, resulted in the largest explained variance: 26\% (forefoot), 34\% (MT1 region), 25\% (MT-2 region), 16\% (MT-3 region), 13\% (MT-4 region) and 29\% (MT-5 region), table 5.

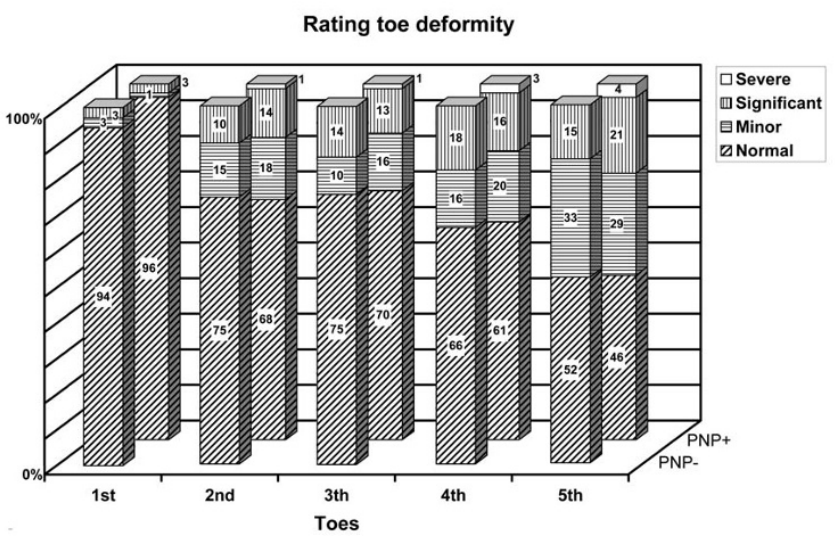

Figure 2

Proportions of toe deformity ratings, as a percentage, for patients with and without neuropathy. Normal $=$ no malalignment whereas minor, significant and severe are respectively defined as less, the same or more deformed than the definitions described by Myerson and Shereff.

\section{Previously proposed regression models}

We used the same radiological measures in the present study as in previous studies by Morag and Cavanagh (1999)[47]. The model for the hallux region, yielded an $r$ of .061 and an $r^{2}$ of .004, SE 0.71 (overall p-value .877).

The models for the MT-1 region proposed by Cavanagh et al (1997)[38], resulted in $r .27, r^{2} .075$, SE $0.51(\mathrm{p}=.007)$ and Morag and Cavanagh (1999)[47], r.31, $r^{2} .10$, SE 0.51 $(\mathrm{p}=.002)$. The only statistically significant beta, also known as beta weight or standardized regression coefficient, in the MT-1 model was 'sesamoid height', i.e. soft tissue thickness under the first metatarsalphalangeal joint.

We also evaluated proposed regression models by Mueller et al.(2003)[48], Ahroni et al. (1999)[49] and Payne et al. (2002)[50] with similar variables from our dataset for the plantar regions concerned. No statistically significant regression models were found for the hallux region.

The models proposed by Mueller et al. for MT-1 (hallux valgus angle, Morton's index, body weight) to MT-3 (hammer toe deformity, soft tissue stiffness, calcaneal inclination) and MT-5 (hammer toe deformity, Morton's index) were statistically significant: MT-1 region $r .32, r^{2}$ .105 SE $0.50(\mathrm{p}=.001)$; MT-2 region $r .32, r^{2} .103$, SE 0.43 $(\mathrm{p}=.001)$; MT-3 region $r .22, r^{2} .046$, SE 0.38, $(\mathrm{p}=.013)$ and MT-5 region $\mathrm{R} .29, r^{2} .072$, SE $0.61(\mathrm{p}=.004)$. This was also true for the model for prediction of plantar pressure under the forefoot by Ahroni et al. (body weight, insulin use) and the model for the MT-1 region suggested by Payne et al. (MTP-1 range of motion, Michigan Neuropathy Score): $r .46, r^{2} .212$, SE $0.19(\mathrm{p}=.001)$ and $r .36$, $r^{2} .131$, SE $0.49(\mathrm{p}=.001)$, respectively.

\section{Bland-Altman analysis}

Figures 3 and 4 show the difference between the observed and predicted peak pressure plotted against their mean for the MT-1 region. Figure 3 shows the results based on the comprehensive regression model and figure 4 shows the results based on the regression model proposed by Cavanagh et al. (1997)[38]. Figures 3 and 4, mean values between $200 \mathrm{kPa}$ and $450 \mathrm{kPa}$, show both positive and negative differences of circa $200 \mathrm{kPa}$, while the difference between the observed and predicted peak pressure increases at higher values.

The dotted lines in figures 3 and 4, indicate the 65 percent range of differences ( $1 \mathrm{SD}$ ) and the range for 95 percent of differences (2 SD).

\section{Discussion}

We explored new and previously suggested relationships between clinical measurements, data from radiographs and barefoot plantar pressure in patients with diabetes. 
Table 4: Radiographic measurements

\begin{tabular}{|c|c|c|c|c|c|c|}
\hline \multirow[b]{2}{*}{ Lateral radiograph } & \multicolumn{3}{|c|}{ PNP- } & \multicolumn{3}{|c|}{ PNP+ } \\
\hline & Mean & SD & Min-Max & Mean & SD & Min-Max \\
\hline Sesamoid height (mm) & 4.6 & 2.35 & $0.5-14$ & 4.2 & 2.63 & $0-15$ \\
\hline MT-5 head height (mm) & 8.3 & 2.21 & $3.5-18$ & 7.7 & 2.23 & $2-13.5$ \\
\hline *MT-5 base height (mm) & 15.4 & 3.91 & $4-26$ & |4.1 & 4.50 & $5-24$ \\
\hline **Navicular height (mm) & 40.8 & 8.66 & $10-60$ & 37.1 & 8.78 & $12.5-53$ \\
\hline Calcaneal height $(\mathrm{mm})$ & 9.5 & 2.91 & $3-20$ & 9.6 & 3.05 & $3-17$ \\
\hline **Inferior calcaneal inclination (deg) & 23.4 & 5.18 & $11-36.5$ & 20.5 & 5.78 & $3-31$ \\
\hline superior calcaneal inclination (deg) & 21.7 & 5.52 & $8.5-35$ & 20.7 & 7.12 & $2-35.5$ \\
\hline *Chopart's joint angle (deg) & 63.3 & 4.43 & $47-75.5$ & 61.9 & 4.83 & $46-71.5$ \\
\hline Navicular Ist cuneiform angle (deg) & 64.0 & 5.20 & $49.5-76.5$ & 64.7 & 4.47 & $56-77.5$ \\
\hline **Lisfranc's joint angle (deg) & 63.3 & 4.03 & $52.5-74$ & 65.3 & 5.09 & $56-86$ \\
\hline **MT-5 inclination (deg) & 12.8 & 3.97 & $3.5-23.5$ & 11.3 & 3.63 & $1-18.5$ \\
\hline *MT-I inclination (deg) & 23.7 & 3.70 & $11.5-33$ & 22.1 & 4.23 & $6.5-30$ \\
\hline **Talar inclination (deg) & 25.0 & 4.86 & $12.5-43$ & 28.0 & 6.22 & $16-49.5$ \\
\hline *Ist PIP joint inclination (deg) & 10.9 & 4.82 & $-3.5-25$ & 8.8 & 7.01 & $-|4-3| .5$ \\
\hline Anterior-posterior radiograph & Mean & SD & Min-Max & Mean & SD & Min-Max \\
\hline *Hallux valgus (deg) & 14.3 & 5.22 & $4-29$ & 16.7 & 10.96 & $1.5-56.5$ \\
\hline Intermetatarsal I-5 angle (deg) & 26.1 & 3.25 & $19-36.5$ & 25.4 & 5.65 & $9.5-41$ \\
\hline Intermetatarsal I-2 angle (deg) & 10.9 & 2.66 & $6-25$ & 10.4 & 3.40 & $5-22$ \\
\hline MTP-I angle (deg) & 14.3 & 5.22 & $4-29$ & 16.7 & 10.96 & $1.5-56.5$ \\
\hline Interphalangeal I angle (deg) & 9.7 & 5.06 & $0-23.5$ & 10.3 & 5.99 & $-10-26$ \\
\hline Medial sesamoid $X$ deviation $(\mathrm{mm})$ & 2.3 & 1.97 & $-2.5-7$ & 1.8 & 3.32 & $-8-8.5$ \\
\hline Medial sesamoid $Y$ deviation (mm) & 12.3 & 2.45 & $6-21$ & 12.2 & 2.40 & $5.5-17.5$ \\
\hline Lateral sesamoid $X$ deviation $(\mathrm{mm})$ & 9.2 & 1.67 & $3.5-16$ & 9.7 & 1.90 & $5-13.5$ \\
\hline Lateral sesamoid $Y$ deviation $(\mathrm{mm})$ & 15.4 & 2.45 & $7.5-21.5$ & 16.0 & 3.11 & $8-24$ \\
\hline Morton's index $(\mathrm{mm})$ & 1.5 & 2.94 & $-6-6.5$ & 1.2 & 3.80 & $-5.5-17$ \\
\hline MT-I thickness (mm) & 13.9 & 1.79 & $10.5-19.5$ & 14.0 & 1.71 & $11-19$ \\
\hline *MT-2 thickness (mm) & 7.3 & 0.85 & $5.5-10$ & 7.7 & 1.07 & $6-12.5$ \\
\hline$* M T-3$ thickness $(\mathrm{mm})$ & 6.4 & 0.71 & $5-8$ & 6.8 & I.II & $5-12$ \\
\hline MT-I lenght $(\mathrm{mm})$ & 65.2 & 5.04 & $56-83.5$ & 66.6 & 4.76 & $55-76.5$ \\
\hline MT- 2 lenght (mm) & 77.4 & 4.96 & $67.5-95.5$ & 78.3 & 5.36 & $64.5-88$ \\
\hline MT- 3 lenght (mm) & 75.1 & 4.96 & $64.5-93$ & 75.9 & 5.74 & $64-90$ \\
\hline MT-4 lenght (mm) & 73.3 & 4.93 & $61-88$ & 74.3 & 5.32 & $54-83$ \\
\hline MT- 5 lenght $(\mathrm{mm})$ & 72.9 & 5.24 & $61-84.5$ & 73.3 & 5.02 & $57-82$ \\
\hline
\end{tabular}

PNP- versus PNP+ * $p<0.05 \& *^{*} p<0.005, \mathrm{PIP}=$ proximal interphalangeal, deg $=$ degree

The primary aim of the present study was to find a minimal combination of measures which could indicate locations with elevated plantar pressure as an alternative for quantitative plantar measurement.

\section{Results from clinical examination and radiographic evaluation}

Consistent with what is reported in the literature, higher peak pressures were measured under the neuropathic forefoot than those under the forefoot without neuropathy[51]. The greatest difference was measured in the MT-1 region. The dorsal flexion motion of the metarsalphalangeal joint of the first toe was less while the hallux valgus angle was greater in neuropathic feet compared to feet without neuropathy. Both observations were previously reported in the literature and are positively correlated with plantar pressure[38,43,52,53].
The distributions of callus formation and toe deformity grades were similar for feet with and without neuropathy. Neuropathic feet had a slightly higher grade of deformity of the $4^{\text {th }}$ and $5^{\text {th }}$ toe. Results from the regression analysis showed that toe deformities were weakly associated with peak pressures in their pertaining forefoot regions. There were no statistically significant differences in calcaneal resting position and arch height between feet with and without neuropathy. Callosities, toe deformity, calcaneal alignment and arch height were previously identified as distinct features in high risk diabetic patients with neuropathy $[1,49,54,55]$. The severity of these clinical symptoms in the patients of this study are relatively mild. This could be the explanation for the minor differences between feet with and without neuropathy. 
Table 5:

\begin{tabular}{|c|c|c|c|c|c|c|c|c|c|c|c|c|c|c|c|c|c|c|}
\hline \multirow[b]{2}{*}{ Region } & \multicolumn{6}{|c|}{ Clinical predictors } & \multicolumn{6}{|c|}{ Radiological predictors } & \multicolumn{6}{|c|}{ Comprehensive model } \\
\hline & Variable & $\boldsymbol{R}$ & $R^{2}$ & $\beta$ & SE & Beta & Variable & $R$ & $R^{2}$ & $\beta$ & SE & Beta & Variable & $\boldsymbol{R}$ & $R^{2}$ & $\beta$ & SE & Beta \\
\hline \multirow{6}{*}{$\begin{array}{l}\text { Fore } \\
\text { foot }\end{array}$} & model & $0,37 \dagger$ & 0,14 & & & & model & $0,42 \dagger$ & 0,18 & & & & model & $0,5 \mathrm{It}$ & 0,26 & & & \\
\hline & Intercept & & & $3,863^{\dagger}$ & 0,038 & & Intercept & & & $4,039 \dagger$ & 0,200 & & Intercept & & & $3,605^{\dagger}$ & 0,065 & \\
\hline & $\begin{array}{r}\text { Valk } \\
\text { score }\end{array}$ & & & $0,019+$ & 0,004 & 0,35 & $\begin{array}{r}\text { MT-I } \\
\text { phalan } \\
\text { angle }\end{array}$ & & & $0,019 \dagger$ & 0,005 & 0,40 & $\begin{array}{r}\text { Valk } \\
\text { score }\end{array}$ & & & $0,028^{\dagger}$ & 0,006 & 0,31 \\
\hline & $\begin{array}{r}\text { Toe } \\
\text { deformity }\end{array}$ & & & $0,017^{\dagger}$ & 0,076 & 0,29 & $\begin{array}{r}\text { Sesamoid } \\
\text { height }\end{array}$ & & & $-0,043 *$ & 0,015 & $-0,20$ & $\begin{array}{c}\text { Callus } \\
\text { sum }\end{array}$ & & & $0,018^{*}$ & 0,006 & 0,21 \\
\hline & & & & & & & $\begin{array}{r}\text { Med } \\
\text { sesam Y } \\
\operatorname{dev}\end{array}$ & & & $-0,053^{*}$ & 0,015 & $-0,24$ & $\begin{array}{r}\text { Moton's } \\
\text { index }\end{array}$ & & & $0,027^{*}$ & 0,008 & 0,22 \\
\hline & & & & & & & & & & & & & $\begin{array}{r}\text { Deviation } \\
\text { hallux rx }\end{array}$ & & & $0,010^{*}$ & 0,003 & 0,20 \\
\hline \multirow[t]{6}{*}{ Hallux } & model & $0,49 \dagger$ & 0,24 & & & & model & $0,38^{\dagger}$ & 0,14 & & & & model & $0.38^{\dagger}$ & 0.14 & & & \\
\hline & Intercept & & & $3,886 \dagger$ & 0,149 & & Intercept & & & $-0,128{ }^{\dagger}$ & 0,708 & & Intercept & & & $-0,175 \dagger$ & 0,704 & \\
\hline & $\begin{array}{r}\text { Callus } \\
\text { formation }\end{array}$ & & & $0,176 \dagger$ & 0,036 & 0,32 & $\begin{array}{r}\text { Nav Ist } \\
\text { cuneifor } \\
\text { m }\end{array}$ & & & $0,040 \dagger$ & 0,010 & 0,28 & $\begin{array}{l}\text { Nav Ist } \\
\text { cuneiform }\end{array}$ & & & $0,040 \dagger$ & 0,010 & 0,28 \\
\hline & $\begin{array}{r}\text { Calcaneu } \\
\text { s varus }\end{array}$ & & & $-0,266^{*}$ & 0,094 & $-0,19$ & $\begin{array}{r}\text { MT-5 } \\
\text { inclinatio } \\
n\end{array}$ & & & $0,033^{*}$ & 0,013 & 0,18 & $\begin{array}{r}\text { MT-5 } \\
\text { inclination }\end{array}$ & & & $0,033^{*}$ & 0,013 & 0,18 \\
\hline & $\begin{array}{r}\text { Dorsal } \\
\text { flex ankle }\end{array}$ & & & $-0,026^{*}$ & 0,008 & 0,22 & $\begin{array}{r}\text { Lat sesam } \\
\text { Y dev }\end{array}$ & & & $0,046 *$ & 0,018 & 0,18 & $\begin{array}{r}\text { Med } \\
\text { sesam Y } \\
\operatorname{dev}\end{array}$ & & & $0,046^{*}$ & 0,018 & 0,18 \\
\hline & $\begin{array}{l}\text { Height } \\
\text { medial } \\
\text { arch }\end{array}$ & & & $-0,15 \mathrm{It}^{\dagger}$ & 0,043 & $-0,23$ & & & & & & & & & & & & \\
\hline \multirow[t]{6}{*}{ MT-I } & model & $0,55^{\dagger}$ & 0,30 & & & & model & $0,42 \dagger$ & 0,19 & & & & model & $0,58 \dagger$ & 0,34 & & & \\
\hline & Intercept & & & $3,102 \dagger$ & 0,058 & & Intercept & & & $4,039 \dagger$ & 0,200 & & Intercept & & & $3,572 \dagger$ & 0,170 & \\
\hline & $\begin{array}{r}\text { Valk } \\
\text { score }\end{array}$ & & & $0,025 \dagger$ & 0,004 & 0,36 & $\begin{array}{r}\text { Sesamoid } \\
\text { height }\end{array}$ & & & $-0,043^{\dagger}$ & 0,015 & $-0,20$ & $\begin{array}{r}\text { Valk } \\
\text { score }\end{array}$ & & & $0,024 \dagger$ & 0,004 & 0,35 \\
\hline & $\begin{array}{r}\text { Ist toe } \\
\text { deformity }\end{array}$ & & & $0,27 I^{*}$ & 0,095 & 0,18 & $\begin{array}{r}\text { Med } \\
\text { sesam Y } \\
\operatorname{dev}\end{array}$ & & & $-0,053^{*}$ & 0,015 & $-0,24$ & $\begin{array}{r}\text { Callus } \\
\text { formation }\end{array}$ & & & $0,133^{\dagger}$ & 0,025 & 0,33 \\
\hline & $\begin{array}{r}\text { Callus } \\
\text { formation }\end{array}$ & & & $0,135^{\dagger}$ & 0,026 & 0,33 & $\begin{array}{r}\text { MT-I } \\
\text { phalan } \\
\text { angle }\end{array}$ & & & $0,019 *$ & 0,005 & $-0,29$ & $\begin{array}{l}\text { Deviation } \\
\text { hallux } r x\end{array}$ & & & $0,012^{*}$ & 0,004 & 0,20 \\
\hline & & & & & & & & & & & & & $\begin{array}{r}\text { Med } \\
\text { sesam Y } \\
\operatorname{dev}\end{array}$ & & & $-0,05 \mathrm{It}$ & 0,014 & $-0,24$ \\
\hline
\end{tabular}


Table 5: (Continued)

\begin{tabular}{|c|c|c|c|c|c|c|c|c|c|c|c|c|c|c|c|c|c|c|}
\hline \multirow[t]{5}{*}{ MT-2 } & model & $0,46^{\dagger}$ & 0,21 & & & & Model & $0,40^{\dagger}$ & 0,16 & & & & model & $0,50^{\dagger}$ & 0,25 & & & \\
\hline & Intercept & & & $3,483 \dagger$ & 0,064 & & Intercept & & & $2,656 \dagger$ & 0,260 & & Intercept & & & $2,607 \dagger$ & 0,237 & \\
\hline & $\begin{array}{r}\text { Callus } \\
\text { formation }\end{array}$ & & & $0,126^{\dagger}$ & 0,026 & 0,33 & $\begin{array}{r}\text { Devi } \\
\text { hallux } r x\end{array}$ & & & $0,016^{\dagger}$ & 0,004 & 0,29 & $\begin{array}{r}\text { Callus } \\
\text { formation }\end{array}$ & & & $0,134^{\dagger}$ & 0,025 & 0,35 \\
\hline & $\begin{array}{r}\text { 2nd toe } \\
\text { deformity }\end{array}$ & & & $0,111 *$ & 0,043 & 0,17 & $\begin{array}{r}M T-2 \\
\text { thickness }\end{array}$ & & & $0,118^{\dagger}$ & 0,032 & 0,25 & $\begin{array}{r}M T-2 \\
\text { thickness }\end{array}$ & & & $0,133^{\dagger}$ & 0,031 & 0,29 \\
\hline & Valk & & & $0,005^{*}$ & 0,002 & 0,19 & $\begin{array}{r}\text { Moton's } \\
\text { index }\end{array}$ & & & $0,027^{*}$ & 0,009 & 0,20 & $\begin{array}{l}\text { 2nd toe } \\
\text { deformity }\end{array}$ & & & $0,145^{*}$ & 0,042 & 0,23 \\
\hline \multirow[t]{5}{*}{ MT-3 } & model & $0,35 t$ & 0,12 & & & & Model & $0,29 \dagger$ & 0,09 & & & & model & $0.40 \dagger$ & 0.16 & & & \\
\hline & Intercept & & & $3,251 t$ & 0,137 & & Intercept & & & $3,531 \dagger$ & 0,059 & & Intercept & & & $3,220 \dagger$ & 0,136 & \\
\hline & $\begin{array}{r}\text { Callus } \\
\text { formation }\end{array}$ & & & $0,102 \dagger$ & 0,024 & 0,30 & $\begin{array}{r}\text { Moton's } \\
\text { index } \\
\text { Dev }\end{array}$ & & & $0,025^{*}$ & 0,008 & 0,22 & $\begin{array}{r}\text { Callus } \\
\text { formation }\end{array}$ & & & $0,098^{\dagger}$ & 0,023 & 0,29 \\
\hline & $\begin{array}{l}\text { Body } \\
\text { Mass } \\
\text { Index }\end{array}$ & & & $0,013^{*}$ & 0,005 & 0,20 & hallux & & & $0,010 *$ & 0,003 & 0,22 & $\begin{array}{r}\text { Body } \\
\text { Mass } \\
\text { Index }\end{array}$ & & & $0,013 *$ & 0,004 & 0,18 \\
\hline & & & & & & & & & & & & & $\begin{array}{r}\text { Moton's } \\
\text { index }\end{array}$ & & & $0,021 *$ & 0,008 & 0,20 \\
\hline \multirow[t]{4}{*}{ MT-4 } & model & $0,26 \dagger$ & 0,07 & & & & Model & $0,25^{\dagger}$ & 0,06 & & & & model & $0,35^{\dagger}$ & 0,13 & & & \\
\hline & Intercept & & & $3,263 \dagger$ & 0,030 & & Intercept & & & $2,030 \dagger$ & 0,371 & & Intercept & & & $2,026 \dagger$ & 0,359 & \\
\hline & $\begin{array}{r}\text { Callus } \\
\text { formation }\end{array}$ & & & $0,095 t$ & 0,026 & 0,26 & $\begin{array}{l}\text { MT-4 } \\
\text { length }\end{array}$ & & & $0,018^{\dagger}$ & 0,005 & 0,25 & $\begin{array}{r}\text { Callus } \\
\text { formation }\end{array}$ & & & $0,091 t$ & 0,025 & 0,25 \\
\hline & & & & & & & & & & & & & $\begin{array}{r}\text { MT-4 } \\
\text { length }\end{array}$ & & & $0,017^{\dagger}$ & 0,005 & 0,24 \\
\hline \multirow[t]{5}{*}{ MT-5 } & model & $0,40 \dagger$ & 0,16 & & & & Model & $0,47 \dagger$ & 0,22 & & & & model & $0,54 \dagger$ & 0,29 & & & \\
\hline & Intercept & & & $2,833^{\dagger}$ & 0,056 & & & & & I,448* & 0,596 & & Intercept & & & 1,933* & 0,575 & \\
\hline & $\begin{array}{r}\text { Callus } \\
\text { formation }\end{array}$ & & & $0,215 t$ & 0,036 & 0,40 & $\begin{array}{l}\text { MT-5 } \\
\text { length }\end{array}$ & & & $0,033^{\dagger}$ & 0,008 & 0,27 & $\begin{array}{r}\text { Callus } \\
\text { formation }\end{array}$ & & & $0,181 \dagger$ & 0,034 & 0,34 \\
\hline & & & & & & & $\begin{array}{r}\text { Moton's } \\
\text { index }\end{array}$ & & & $-0,035^{*}$ & 0,013 & $-0,18$ & $\begin{array}{r}\text { MT-5 } \\
\text { length }\end{array}$ & & & $0,023^{*}$ & 0,018 & 0,19 \\
\hline & & & & & & & $\begin{array}{r}\text { MT-5 } \\
\text { head } \\
\text { height }\end{array}$ & & & $-0,096^{\dagger}$ & 0,019 & $-0,34$ & $\begin{array}{r}\text { MT-5 } \\
\text { head } \\
\text { height }\end{array}$ & & & $-0,093 \dagger$ & 0,008 & $-0,33$ \\
\hline
\end{tabular}


Relatively many differences were found for measurements on lateral radiographs compared to anterior-posterior radiographs. The soft tissue thickness under the head of MT-5 is greater in patients without neuropathy, which could be an explanation for the lower peak pressure in this region compared to patients with neuropathy. A similar relationship between soft tissue thickness and peak pressure exists for MT-1 and was reported in previous studies $[5,38,56]$.

Various radiological parameters indicate that neuropathic feet have a lower arch structure than feet without neuropathy. Some parameters obtained from lateral and anteriorposterior radiographs indicate similar classifications found through clinical examination, such as arch height and hallux alignment, although no statistically significant differences were found.

\section{Regression models}

In general, the regression models with selected clinical variables explained more variance in plantar pressure data than the models with only radiological measures, suggesting that clinical examination tells us more about plantar pressure than information from radiographs.

For most regions, the prediction of plantar pressure improved with the combination of radiological and clinical data. The results show that clinical and radiological measurements, either independently or in combination, could explain only about 34 percent of the variance in local bare foot peak pressure. In other words, with the models constructed we have only 34 percent of useful information from the clinical and radiological measurements to make an prediction about the actual bare foot peak pressure.

The Bland-Altman method was used for a visual impression of the individual difference between the predicted and the actual pressure values. We evaluated the comprehensive regression model for the MT-1 region. The scattered data along the wide interval of the horizontal axis in figure 3 show a great variation. The considerable discrepancy between the predicted and the actual peak pressure indicating the inadequacy of the model, especially with regard to the underestimation of high plantar pressure values, i.e. $>700 \mathrm{kPa}$, for which an accurate estimation is highly important.

In general, the previously reported regression models with independent variables from clinical examination showed similar results to our study. Ahroni et al. (1999) claimed that high in-shoe plantar pressure in diabetic subjects (1,017 feet) could be predicted through the use of clinical variables, such as body mass, insulin use, Caucasian race, male sex, plantar callus and diabetes duration[49]. Only 12 percent of the variation was explained. Although Ahroni in his study found body mass to be identified as the most important factor, Cavanagh et al. (1991) found that body mass was a poor predictor[57].

Various predictive models relating plantar peak pressure and structural variables obtained through imaging techniques have been suggested)[38,47-49,58-62]. Cavanagh et al. presented a model which explained approximately 40 percent of the variance in forefoot pressure during walking with 3 to 4 static structural measurements from foot radiographs of healthy subjects[38]. While we found a similar result, 34 percent of explained variance is not sufficient for prediction of plantar pressure.

\section{Prediction models with the same or similar parameters applied to the present data set}

Various regression models with demographically, clinically and radiologically independent variables have been suggested in the literature to estimate local plantar pressure in patients with diabetes. Comparison of these models is difficult. Various methodological aspects are different such as the population characteristics, the choice of the plantar pressure parameters and how the data of the independent variables were obtained. Despite these differences, we constructed regression models with the same or similar parameters and applied these models to our data set.

We used radiological measures identical to those used by Morag and Cavanagh (1999)[47] for the prediction of barefoot peak pressure, but we could reach only 13 percent explained variance. Cavanagh et al. (1997)[38] suggested four radiological measures for peak pressure in the MT-1 region. This model was also evaluated with our data and analysed with the Bland-Altman method (figure 4). Similarly modest results as for our own comprehensive MT-1 model (figure 3) were found. Twenty-one percent was the highest explained variance found, with the regression models formulated by Mueller et al.(2003)[48], Ahroni et al. (1999)[49] and Payne et al. (2002)[50], which implies that these models are not useful when applied to the data of the present study.

This study was directed from a practical and ecological research perspective, which means that the patients were mostly screened according through common practice procedures: e.g. goniometry, blood pressure measurements, etc. According to scientific criteria, these common practice procedures often have inferior clinimetric qualities and are likely to contribute to inherent variability. Maybe other clinical or radiological measurements are less prone to inherent variability and may be stronger predictors for 


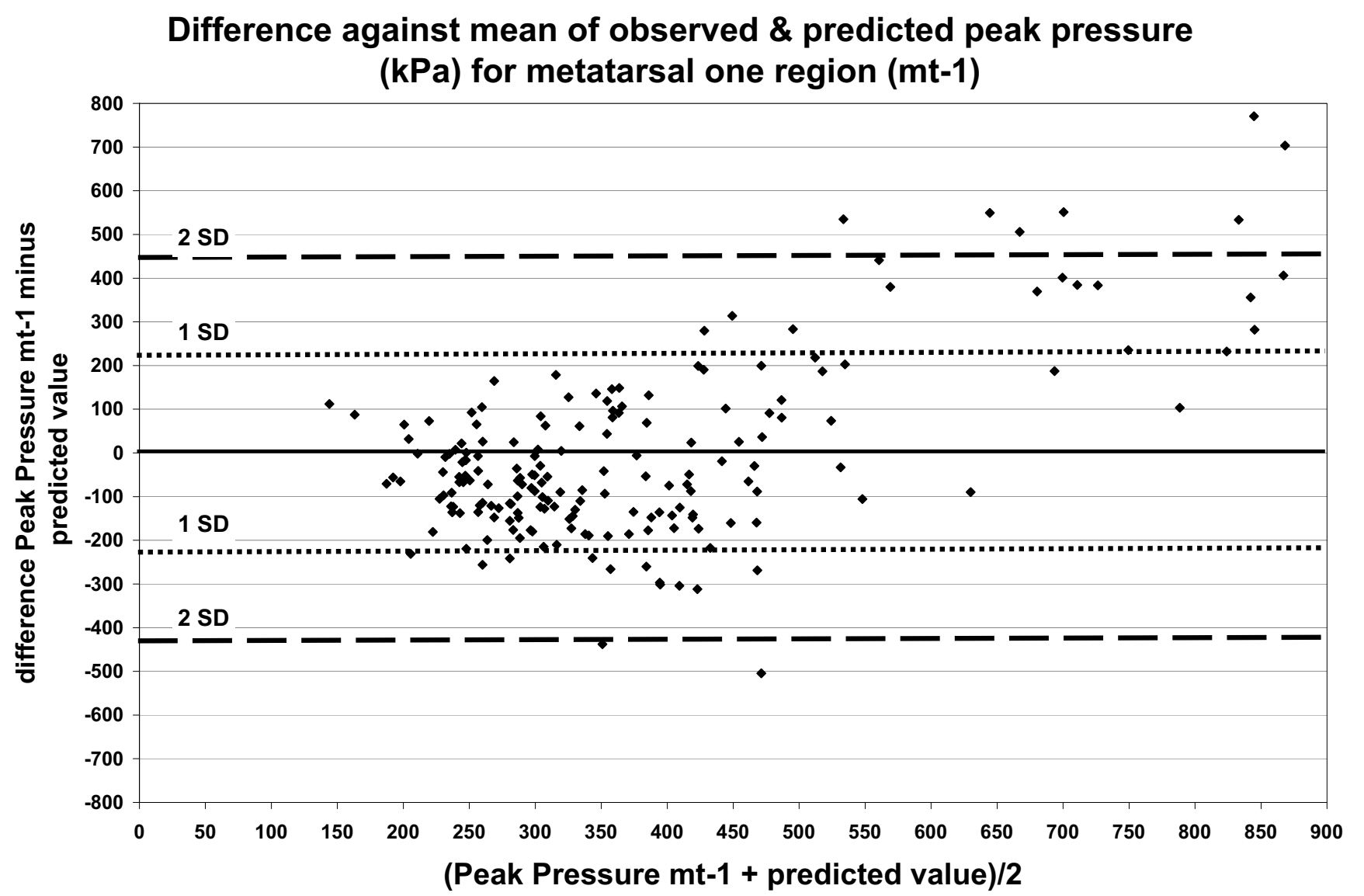

Figure 3

The difference between the observed and predicted peak pressure plotted against the mean ( $\mathrm{kPa})$, based on the comprehensive regression model for MT-I region. Comprehensive model ( $\left.r^{2} 34 \%\right)$. Independent variables: Valk score, Deviation hallux x-ray, Callus formation, Medial sesamoid Y-axis deviation.

local peak pressure. We studied diabetic patients without foot complications such as severe deformities and gait abnormalities. Some of the results might well be different in patients with these complications of diabetes. Nevertheless, we think it is important to identify patients with elevated plantar pressures in their early stage of disease in order to take appropriate preventive measures. The screening of these kind of patients is typically done in peripheral care centres where there is no radiological facility or plantar pressures equipment are available.

Clinical signs are potentially more cost-effective than sophisticated diagnostic tests which are less feasible in community settings. However, the results form this study confirm the conclusions of a previous study which showed that identification of locations with elevated plantar pressure is not possible through physical examination[63]. The use of radiological measures does not provide a better prediction of local barefoot peak pressure.
There is a clear need for further research to address these clinical uncertainties. The use of quantitative plantar pressure measurement is therefore advocated for diabetic foot care.

\section{Conclusion}

Peak pressures were higher in patients with neuropathy than in patients without neuropathy, although feet were quite similar as far as clinical and radiological evaluations is concerned. At best, clinical and radiological measurements could explain about 34 percent of the variance in local barefoot peak pressure in this population of diabetic patients. The prediction models constructed with regression modeling were not useful in clinical practice, because of considerable discrepancies between the predicted and the actual peak pressure values. Identification of elevated plantar pressure without equipment for quantification of plantar pressure is inadequate. This points toward the 


\section{Difference against mean of observed $\&$ predicted peak pressure (kPa) for metatarsal one region (mt-1) model Cavanagh 1997}

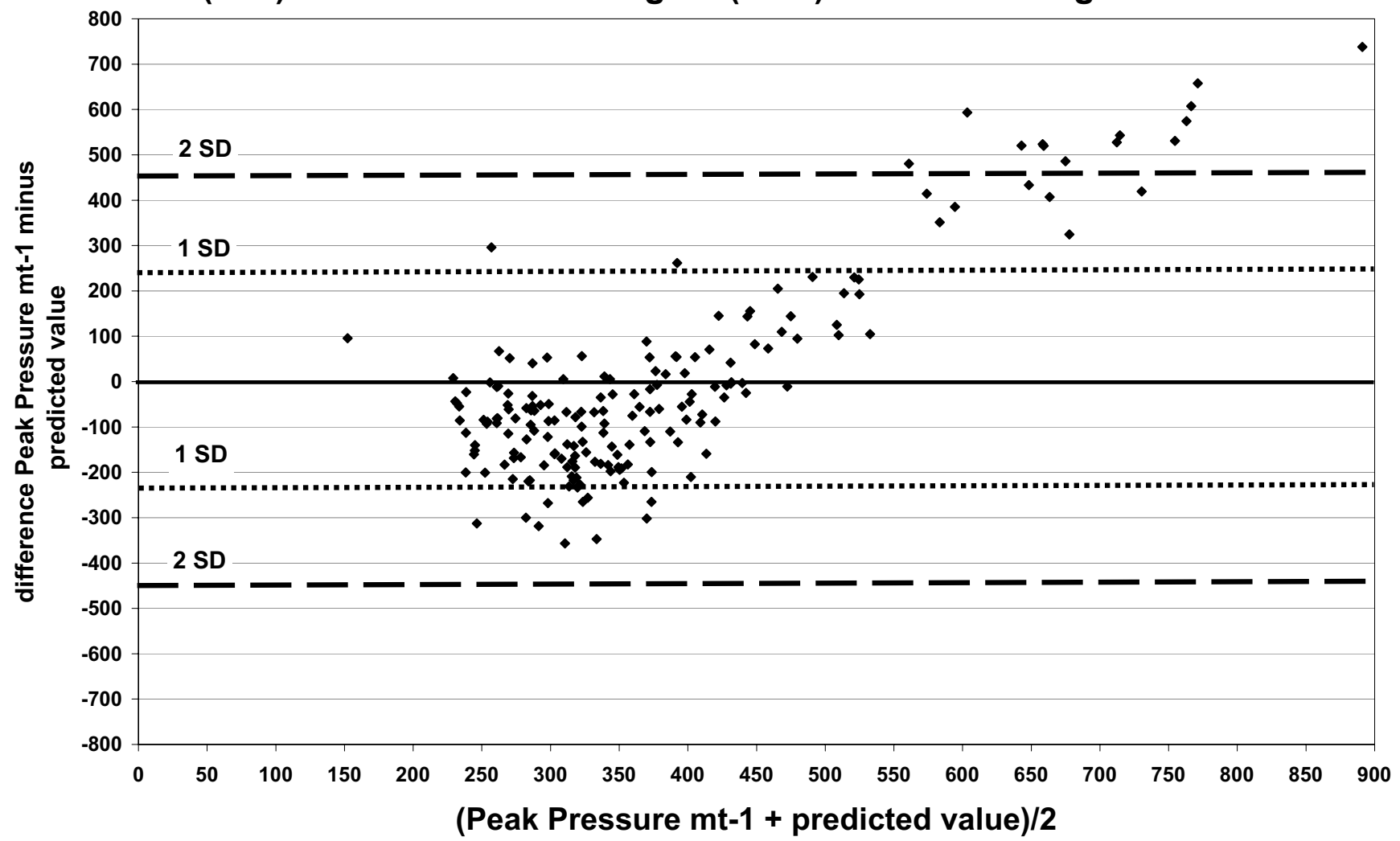

Figure 4

The difference between the observed and predicted peak pressure plotted against the mean $(\mathrm{kPa})$, based on the regression model for MT-I region stated by Cavanagh et al. (1997). Model with radiological variables $\left(r^{2} 38 \%\right)$. Independent variables: Ist Metatarsal length, Sesamoid height, Ist Metatarsal-phalangeal angle.

merit of quantitative plantar pressure measurement for diabetic foot screening.

\section{Acknowledgements}

This study was supported by the Dutch Diabetes Research Foundation. We thank patients who participated in this study.

\section{References}

I. Crawford F, Inkster M, Kleijnen J, Fahey T: Predicting foot ulcers in patients with diabetes: a systematic review and meta-analysis. Qjm 2007, 100(2):65-86.

2. Zimny S, Schatz $\mathrm{H}$, Pfohl M: The role of limited joint mobility in diabetic patients with an at-risk foot. Diabetes Care 2004, 27(4):942-946.

3. Fernando DJ, Masson EA, Veves A, Boulton AJ: Relationship of limited joint mobility to abnormal foot pressures and diabetic foot ulceration. Diabetes Care 199I, I 4(I):8-II.

4. Ledoux WR, Hillstrom $\mathrm{HJ}$ : The distributed plantar vertical force of neutrally aligned and pes planus feet. Gait Posture 2002, I5(I): I-9.

5. Abouaesha F, van Schie CH, Armstrong DG, Boulton AJ: Plantar soft-tissue thickness predicts high peak plantar pressure in the diabetic foot. J Am Podiatr Med Assoc 2004, 94(I):39-42.
6. Spears IR, Miller-Young JE, Waters M, Rome K: The effect of loading conditions on stress in the barefooted heel pad. Med Sci Sports Exerc 2005, 37(6): 1030-1036.

7. Miller-Young JE, Duncan NA, Baroud G: Material properties of the human calcaneal fat pad in compression: experiment and theory. J Biomech 2002, 35( I 2): I523-I53I.

8. Aerts P, Ker RF, de Clercq D, Ilsley DW: The effects of isolation on the mechanics of the human heel pad. J Anat 1996, I88(Pt 2):417-423.

9. Weijers RE, Walenkamp GH, Kessels AG, Kemerink GJ, van Mameren H: Plantar pressure and sole thickness of the forefoot. Foot Ankle Int 2005, 26( I 2): 1049-1054.

10. Gefen A, Linder-Ganz E: Diffusion of ulcers in the diabetic foot is promoted by stiffening of plantar muscular tissue under excessive bone compression. Orthopade 2004, 33(9):999-10I2.

II. Ledoux WR, Meaney DF, Hillstrom HJ: A quasi-linear, viscoelastic, structural model of the plantar soft tissue with frequency-sensitive damping properties. I Biomech Eng 2004, 126(6):83|-837.

12. Bevans JS, Bowker P: Foot structure and function: aetiological risk factors for callus formation in diabetic and non-diabetic subjects. The Foot 1999:120-127.

13. Pitei DL, Foster A, Edmonds M: The effect of regular callus removal on foot pressures. J Foot Ankle Surg I999, 38(4):25 I-255.

14. Gefen A: Plantar soft tissue loading under the medial metatarsals in the standing diabetic foot. Med Eng Phys 2003, 25(6):49|-499. 
15. Klaesner JW, Hastings MK, Zou D, Lewis C, Mueller MJ: Plantar tissue stiffness in patients with diabetes mellitus and peripheral neuropathy. Arch Phys Med Rehabil 2002, 83(I 2): I796-I80|

16. Menz HB, Zammit GV, Munteanu SE: Plantar pressures are higher under callused regions of the foot in older people. Clin Exp Dermatol 2007, 32(4):375-380.

17. Colagiuri S, Marsden LL, Naidu V, Taylor L: The use of orthotic devices to correct plantar callus in people with diabetes. Diabetes Res Clin Pract 1995, 28(1):29-34.

18. Duke H, Newman LM, Bruskoff BL, Daniels R: Relative metatarsa length patterns in hallux abducto valgus. J Am Podiatry Assoc 1982, 72(I): I-5.

19. Morton DJ: The Human Foot. New York.: Columbia University; 1935.

20. Roukis TS: Metatarsus primus elevatus in hallux rigidus: fact or fiction? J Am Podiatr Med Assoc 2005, 95(3):22I-228.

21. Simkin A, Leichter I, Giladi M, Stein M, Milgrom C: Combined effect of foot arch structure and an orthotic device on stress fractures. Foot Ankle 1989, I0(I):25-29.

22. Gefen A, Megido-Ravid M, Itzchak Y, Arcan M: Biomechanical analysis of the three-dimensional foot structure during gait: a basic tool for clinical applications. J Biomech Eng 2000, 122(6):630-639.

23. Root ML, Orien WP, Weed JH: Normal and abnormal function of the foot. Los Angeles CA.: Clinical Biomechanics Corporation Publishers; 1977.

24. Camacho DL, Ledoux WR, Rohr ES, Sangeorzan BJ, Ching RP: A three-dimensional, anatomically detailed foot model: a foundation for a finite element simulation and means of quantifying foot-bone position. J Rehabil Res Dev 2002, 39(3):40I-4I0.

25. Ledoux WR, Shofer JB, Smith DG, Sullivan K, Hayes SG, Assal M, Reiber GE: Relationship between foot type, foot deformity, and ulcer occurrence in the high-risk diabetic foot. J Rehabil Res Dev 2005, 42(5):665-672.

26. Ledoux WR, Shofer JB, Ahroni JH, Smith DG, Sangeorzan BJ, Boyko EJ: Biomechanical differences among pes cavus, neutrally aligned, and pes planus feet in subjects with diabetes. Foot Ankle Int 2003, 24(II):845-850.

27. Myerson MS, Shereff MJ: The pathological anatomy of claw and hammer toes. J Bone Joint Surg Am I989, 7 I (I):45-49.

28. Rodgers MM: Dynamic foot biomechanics. J Orthop Sports Phys Ther 1995, 2 I (6):306-316.

29. van Deursen RW, Sanchez MM, Derr JA, Becker MB, Ulbrecht JS, Cavanagh PR: Vibration perception threshold testing in patients with diabetic neuropathy: ceiling effects and reliability. Diabet Med 200I, 18(6):469-475.

30. Dyck PJ, O'Brien PC: Quantitative sensation testing in epidemiological and therapeutic studies of peripheral neuropathy. Muscle Nerve 1999, 22(6):659-662.

31. Leeden $M$ van der, Dekker JH, Siemonsma PC, Lek-Westerhof SS, Steultjens MP: Reproducibility of plantar pressure measurements in patients with chronic arthritis: a comparison of one-step, two-step, and three-step protocols and an estimate of the number of measurements required. Foot Ankle Int 2004, 25( I 0):739-744.

32. Bus SA, Lange A: A comparison of the I-step, 2-step, and 3-step protocols for obtaining barefoot plantar pressure data in the diabetic neuropathic foot. Clin Biomech (Bristol, Avon) 2005, 20(9):892-899.

33. Weijers RE, Walenkamp GH, van Mameren H, Kessels AG: The relationship of the position of the metatarsal heads and peak plantar pressure. Foot Ankle Int 2003, 24(4):349-353.

34. Franse LV, Valk GD, Dekker JH, Heine RJ, van Eijk JT: 'Numbness of the feet' is a poor indicator for polyneuropathy in Type 2 diabetic patients. Diabet Med 2000, I 7(2): I05-1I0.

35. Valk GD, de Sonnaville JJ, van Houtum WH, Heine RJ, van Eijk JTM, Bouter LM, Bertelsmann FM: The assessment of diabetic polyneuropathy in daily clinical practice: reproducibility and validity of semmes weinstein monofilaments examination and clinical neurological examination. Muscle \& Nerve 1997 20:116-118

36. Engelberg $A L$, ed.: Guides to the Evalaution of Permanent Impairment. 3rd edition. Chicago: American Medical Association 1988.
37. AAOS: Joint Motion: Method of Measuring and Recording. Chicago: Churchill-Livingstone; 1965

38. Cavanagh PR, Morag E, Boulton AJ, Young MJ, Deffner KT, Pammer SE: The relationship of static foot structure to dynamic foot function. J Biomech 1997, 30(3):243-250.

39. Steel MW 3rd, Johnson KA, DeWitz MA, Ilstrup DM: Radiographic measurements of the normal adult foot. Foot Ankle 1980 I(3): $151-158$

40. Saltzman CL, Brandser EA, Berbaum KS, DeGnore L, Holmes JR, Katcherian DA, Teasdall RD, Alexander IJ: Reliability of standard foot radiographic measurements. Foot Ankle Int 1994, I5(I 2):66I-665.

41. Bryant JA: A comparison of radiographic foot measurements taken in two different positions. J Am Podiatr Med Assoc 200I, 9l(5):234-239.

42. Kilmartin TE, Barrington RL, Wallace WW: The x-ray measurement of hallux valgus: an inter- and intra-observer error study. The Foot 1992, 2(I):7-II.

43. Cavanagh PR, Young MJ, Adams JE, Vickers KL, Boulton AJ: Radiographic abnormalities in the feet of patients with diabetic neuropathy. Diabetes Care 1994, I7(3):201-209.

44. Harrell FE: Regression Modeling Strategies: With Applications to Linear Models, Logistic Regression and Survival Analysis. New York: Springer-Verlag; 2001.

45. Rencher AC: Methods of Multivariate Analysis. Second edition. New York: Wiley-Interscience; 2002

46. Bland JM, Altman DG: Statistical methods for assessing agreement between two methods of clinical measurement. Lancet 1986, I(8476):307-3 I0.

47. Morag E, Cavanagh PR: Structural and functional predictors of regional peak pressures under the foot during walking. I Biomech 1999, 32(4):359-370.

48. Mueller MJ, Hastings M, Commean PK, Smith KE, Pilgram TK, Robertson $D$, Johnson J: Forefoot structural predictors of plantar pressures during walking in people with diabetes and peripheral neuropathy. J Biomech 2003, 36(7):1009-1017.

49. Ahroni JH, Boyko EJ, Forsberg RC: Clinical correlates of plantar pressure among diabetic veterans. Diabetes Care 1999, 22(6):965-972.

50. Payne C, Turner D, Miller K: Determinants of plantar pressures in the diabetic foot. J Diabetes Complications 2002, I6(4):277-283.

5I. Frykberg RG, Lavery LA, Pham H, Harvey C, Harkless L, Veves A: Role of neuropathy and high foot pressures in diabetic foot ulceration. Diabetes Care 1998, 2I(I0): 17|4-1719.

52. Turner DE, Helliwell PS, Burton AK, Woodburn J: The relationship between passive range of motion and range of motion during gait and plantar pressure measurements. Diabet Med 2007, 24( I I): I 240- I 246

53. van Gheluwe B, Dananberg HJ, Hagman F, Vanstaen K: Effects of hallux limitus on plantar foot pressure and foot kinematics during walking. Am Podiatr Med Assoc 2006, 96(5):428-436.

54. Boyko EJ, Ahroni JH, Stensel V, Forsberg RC, Davignon DR, Smith DG: A prospective study of risk factors for diabetic foot ulcer. The Seattle Diabetic Foot Study. Diabetes Care 1999, 22(7): 1036-1042

55. Veves A, Murray HJ, Young MJ, Boulton Al: The risk of foot ulceration in diabetic patients with high foot pressure: a prospective study. Diabetologia 1992, 35(7):660-663.

56. Abouaesha F, van Schie CH, Griffths GD, Young RJ, Boulton AJ: Plantar tissue thickness is related to peak plantar pressure in the high-risk diabetic foot. Diabetes Care 200 I, 24(7): I 270-I 274

57. Cavanagh PR, Sims DS Jr, Sanders LJ: Body mass is a poor predictor of peak plantar pressure in diabetic men. Diabetes Care | 991 | | 4(8): 750-755

58. Rosenbaum D, Hautmann S, Gold M, Claes L: Effects of walking speed on plantar pressure patterns and hindfoot angular motion. Gait \& Posture 1994:191-197.

59. Payne $C B$ : Biomechanics of the foot in diabetes mellitus. Some theoretical considerations. J Am Podiatr Med Assoc 1998 , 88(6):285-289.

60. Morag E, Pammer S, Boulton A, Young M, Deffner K, Cavanagh P: Structural and functional aspects of the diabetic foot. Clin Biomech (Bristol, Avon) 1997, I 2(3):S9-SIO. 
6I. Mueller MJ, Minor SD, Diamond JE, Blair VP 3rd: Relationship of foot deformity to ulcer location in patients with diabetes mellitus. Phys Ther 1990, 70(6):356-362.

62. Mueller MJ, Salsich GB, Bastian AJ: Differences in the gait characteristics of people with diabetes and transmetatarsal amputation compared with age-matched controls. Gait \& Posture 1998, 7(3):200-206.

63. Guldemond NA, Leffers P, Nieman FH, Sanders AP, Schaper NC, Walenkamp GH: Testing the proficiency to distinguish locations with elevated plantar pressure within and between professional groups of foot therapists. BMC Musculoskelet Disord 2006, 7:93.

\section{Pre-publication history}

The pre-publication history for this paper can be accessed here:

http://www.biomedcentral.com/1472-6823/8/16/prepub

Publish with Bio Med Central and every scientist can read your work free of charge

"BioMed Central will be the most significant development for disseminating the results of biomedical research in our lifetime. "

Sir Paul Nurse, Cancer Research UK

Your research papers will be:

- available free of charge to the entire biomedical community

- peer reviewed and published immediately upon acceptance

- cited in PubMed and archived on PubMed Central

- yours - you keep the copyright

Submit your manuscript here:

http://www.biomedcentral.com/info/publishing_adv.asp 